\title{
The state, End SARS protests and human rights violation in Nigeria
}

\author{
Kenneth Chinedu Asogwa ${ }^{1}$, Herbert C. Edeh², Anthony Chinonso Ajah², Paul Hezekiah \\ $\mathrm{Omeh}^{2}$, Mathias Ikechukwu Asadu ${ }^{3}$, Damian Chimezie Ogbuabor ${ }^{4}{ }^{*}$ Elias C. Ngwu ${ }^{2}$
}

\author{
University of Nigeria, Nsukka: \\ 'Institute of African Studies, \\ ${ }^{2}$ Department of Political Science, \\ ${ }^{3}$ Department of History and International Studies, \\ ${ }^{4}$ Department of Library and Information Science, \\ *Correspondence: elias.ngwu@unn.edu.ng
}

\begin{abstract}
In November 2017, there was an online protest against police brutality and highhandedness in Nigeria. By October 2020, the citizens' discontent and dissatisfaction with the activities of the police led to a mass revolt against the institution, specifically against the Special Anti-Robbery Squads (SARS) of the force. The response of the Nigerian state to the protest was total repression and subjugation of the demonstrators. Given the scale of the protest and the government's response, this momentous event has attracted scholarly attention. The extant literature has identified governance deficit, illiteracy of police officers, the dynamics of the political economy and youth activism as factors that fueled the protest. The present study, therefore, explores the character of the state in the post-colonial society as a link towards the understanding of the fundamental issues that triggered the protests. Through the use of
\end{abstract}


secondary sources of data collection and content analysis, the work found out that there is a trend and pattern of authoritarian governance and violation of human rights by the Nigerian state, which seems to have emanated from the long years of military rule and colonisation. The implication of the foregoing is that the state ought to imbibe democratic ethos as a condition for upholding the fundamental human rights of its citizens.

Keywords: State, EndSARS Protest Theory of state in Post-Colonial Society, human rights.

\section{Introduction}

At the beginning of the 21st century, there was the optimism that the century belongs to Africa, having lost the 20th century to rudderless political leadership, worsening economic crisis, corruption, conflicts and failed state syndrome (this was known as Afro-optimism). However, this optimism was diluted with circumspection given different predictions that Africa would still contend with state-induced violence against its citizens in the new millennium. It was predicted that "it is unlikely that Africa will be able to silence the guns by 2020 or by 2023 " and that "a high level of riots and protests will continue to be witnessed in Sub-Sahara Africa" (Colliers, 2018: 2). This has been the case in so many African countries, such as the Democratic Republic of the Congo, Central African Republic, Libya, South Africa, Egypt, Nigeria and many others. Ever since the Arab Spring of the 2010s, there has been a reoccurrence of deafening riots and protests in different African countries. Most of these riots spring up as a result of citizens' discontent with policy implementation and the desperate attempts by political leaders to defend themselves from the authoritarianism of their governments.

Between 2017 and 2020, there were mass protests against police brutality and impunity in Nigeria. Amnesty International notes that there is abundant evidence of police torture of civilians, denying people arrested by the police access to the justice system, the partiality of the judges when administering justice, the inability of the police to address the complaints of the arrested and extrajudicial killings. Worse still, the relevant authorities have refused to investigate and bring to book the police officers who perpetrate these 'crimes' against the people (Amnesty International, 2020). The police also profile and 
dehumanize ordinary citizens who they see as criminals simply because they belong to certain groups (e.g., musicians, footballers and those in possession of modern gadgets like phones and cars) (Amuta, 2020). Amid these atrocities, there has been a public outcry against the excesses of police on social media, and by 2017, there was an online protest where about 28 million individuals from home and in the diaspora tweeted with the hashtag \#ENDSARS to demand the disbanding of the unit of the police known as Special Anti-Robbery Squads (SARS), which is notorious for its brutality against the people.

The EndSARS protest is equally contextualized within the deteriorating material conditions of life in Nigeria owing to how the government responded to the Covid-19 pandemic. Nigeria confirmed its first positive case of Covid-19 in February 2020 and responded to the global lockdown, which started from Lagos and Abuja, without adequate social provisions. There was an announcement of palliatives, but it was characterized by outright lopsidedness and deliberate mismanagement such that most of the vulnerable people were shortchanged (Eranga, 2020). It is not difficult to imagine the negative impacts of ill- treatment on the people, given that the Nigerian economy thrives in the informal sector. By the time the news filtered that the SARS had brutalized an individual in Ugheli, Delta State, people began to unleash their anger on the police on social media. As the protest started, many other young Nigerians, especially those from the tech-oriented community, musicians, and other celebrities, shared their own ugly, lamentable experiences from SARS on Twitter, Facebook, WhatsApp and other social media platforms.

The protesters demanded the abolition of SARS, immediate release of all arrested protesters, provisions of appropriate compensation for the families of the victims of police brutality, the establishment of an independent panel of inquiry on police brutality both at the federal and state levels and increasing the salary of police officers. The federal government swiftly had a meeting with the leadership of the National Assembly, the police and the Human Rights Commission and resolved to dissolve, with immediate effect, the notorious police unit and replace it with Special Weapons and Tactics Team (SWAT). It was also resolved that various panels of inquiry should be established at the states and the federal level to investigate people's 
complaints against SARS. Some of the panels, like the Lagos state panel, paid some compensation to the victims of police brutality (Vanguard, 12 October 2020). In light of this background, the focus of the analysis is to examine the repercussions of police brutality and impunity, which triggered the recent \#EndSARS protest. This work is categorised thus: introduction, conceptualization and theoretical framework, the origin of police in Nigeria, institutional mechanisms of human rights protection, graphic presentation of human rights abuse by SARS in the past and during the \#EndSARS protests and concluding remarks.

\section{Conceptual and theoretical considerations}

Traditionally, the conceptualization of state has always been seen as either from the liberal or the radical perspective. Generally, liberal scholars assert that the state is a neutral umpire in social class competition. According to Adam Smith (1776, cited in Appadorai (1974), the purpose of the state is to protect society from external violence, injustice and the erection of impartial institutions that moderate human conflicts. Similarly, Lin (1993), cited in Okolie (2008:74), defines the state as a territorial human society that exercises influence through a government's supreme coercive power over individuals and groups within the state in order to regulate and maintain a general hierarchy of social values and institutions. Ake captured the generic character of the liberal state when he observed that the state is "a specific modality of class domination, a modality in which class domination is autonomized," arguing that the "institutional mechanisms of class domination are constituted in a way that they enjoy independence from society" (Ake, 1985: 105-106,108-109). By this definition, Ake doubted the appropriateness of the notion of the modern state in Africa. He rather saw African states as states in the process of formation. This means that these states have not transcended the peculiar character of traditional societies and have limited penetration of capitalism (Ake, 1985). However, Ibeanu (1993) has refuted Ake's view of autonomy as an essence of the state. He rather sees domination as the essence of the state.

On the other hand, the Marxian mode of analysis arose in opposition to the AngloAmerican narrative that the state is a neutral and impartial entity, especially regarding the struggles of the social 
classes. Marxism-oriented scholars have essentially seen the state from three different perspectives, namely the instrumentalists, the independents and the instrumentalists (Onuoha, 1992). The instrumentalist perspective conjures the idea of state as a tool for accomplishing the interest of the ruling class while the independents view the state as a neutral arbiter in the social class contestation and the institutionalists believe that the state cannot be touched but can be felt by the existence of various organs of the state like the legislature, the executive, the judiciary, the armed forces and education. This idea is driven by Marx's description of the executive of the mordern state but as a committee for managing the common affairs of the whole bourgeoisie. However, scholars of third world countries like Alavi (1972), Ake (1985), Ekekwa (1986), amongst others, have expanded this theory of the state. Their assumptions have illuminated the basic characteristics of the state in post-colonial societies and have equally provided enlightenment regarding the state's human rights violations. The basic assumption of the theory is that post-colonial states are products of colonialism and, as such, have followed the developmental patterns dictated by the interest of the imperial masters and their local partners rather than the interests of the majority of the indigenous population.

At this juncture, it is imperative to examine what causes the state to infringe on the human rights of its citizens, which has been examined in extant literature. In the literature, there are two broad views regarding why the state infringes on the human rights of its citizenry: the natural law view and the positivist view. The natural law view believes that human rights are rights enjoyed by a man which guarantees their humanity. According to this perspective, these rights are intrinsic to man. Implicit in this view is the idea of the universalization of human rights because it is a derivative of the natural law. The doctrine presupposes that there is a point of convergence in various cultures of humanity. In other words, some interrelated norms and conventions bind the human race together no matter their geographical locations (Garcia, 2017). Mehmet (2015) noted that its major assumptions are: that there is a higher law above human law and that it exists whether discovered by man or not. Implicit in the above assumptions is that violations of human rights, whether by state actors or its agents, spring from illiteracy or improper education. 
This perspective is best represented by Nzarga's (2014) argument that what causes the police to infringe on the human rights of Nigerians is the illiteracy of the citizens and the police. According to him, many Nigerians are uneducated and do not even know when their rights are being violated, and policemen and military men, owing to corruption and illiteracy, do not even know that some citizens are entitled to some rights. Some policemen and the military entered the force through questionable processes such as forging entry certificates (Nzarga, 2014). Oromareghake, Oluka and Adishi (2018) also argued that the consistent abuse of power by the police is a result of ineptitude and lack of knowledge of the law. Maduka (2014), on his part, conducted a case study of the impact of training on police jobs, using Zone 9 , Umuahia, as a unit of analysis. He found out that the police personnel are not adequately trained, while the few who are trained are rarely deployed to their areas of expertise and competency (Maduka, 2014). But the question is, how much knowledge is enough, and to what extent can knowledge (alone) salvage the situation? The Nigerian government's response to the \#ENDSARS protests suggests that the SARS brutality is a manifestation of the poor training of the officers. The federal government proposed the retraining of the officers of SWAT, the new department to replace SARS. Several voices (e.g., Aborishade and Obileye, 2018; Maduekwe-ekwe and Obayemi, 2019;
Amnesty International, 2020) believe that the root causes of human rights violations in Nigeria are a combination of wideranging factors, namely lack of capacity to conduct criminal investigations, low level of education among police officers, poverty, inadequate manpower and lack of equipment. While the enumerated factors may account for why the security apparatus infringe on the fundamental rights of Nigerians, they appear insufficient in explaining the persistent and reoccurring incidence of authoritanrian governance by the Nigerian state.

The second view is the positivist view, otherwise known as the realist view of the law, which is championed by John Austin. According to this view, the law is the order of a sovereign backed by a threat of sanctions in the event of non-compliance (Mehmet, 2015). It sees law as a coercive order created by human communities to protect people from one another and rights as entitlements granted by the law (O'manique, 1992). This notion implies that sanction is attached to the noncompliance of law and that law emanates from the will of the sovereign. It equally gives the impression that the sovereign is above the law since it emanates from him. Expanded further, this view of the law champions the relativity and sociology of law and human rights. Writing on this 
matter, Troper (2011, cited in InvernizziAccetti, 2017:2) observed that "If the expression 'human rights are meant to designate rights that human beings would possess and exercise independently of the state, or even against it, then from a strictly positivist point of view the question is easily resolved: there are no human rights." Similarly, Dyzenhaus (1992: 83) maintains that "[P]ositivism's slogan 'law is law' is the legal expression of the authoritarian ideology which states that judges have a moral obligation to apply, and citizens to obey, the law whatever its content." This realist interpretation of the law can jeopardize and justify human rights violations. Brodgen (2002, cited in Oromareghake, Oluka and Adishi, 2018) also noted that the "police force is structured organizationally and ideologically to act against the marginal strata."

The Nigerian constitution contains such positivist elements. For instance, the 1999 constitution of Nigeria, section $33,\left(a_{1}\right)(b)$ and (c) posits that a person shall not be regarded as having been deprived of his life if he dies as a result of the use of force to defend any person from unlawful violence, to prevent the escape of a person lawfully detained and suppressing of a riot, insurrection or mutiny. This constitutional provision implies that the government has the discretion to determine when the human right has been abused and when it has not. They can kill people in the course of riots and protests and explain that they are relying on the above constitutional provision. Similarly, Kania and Mackey, 1977, cited in Lyle and Esmail, 2016) observed that the use of force by the police might be considered necessary or excessive depending on the police's interpretation.

The same strands of thought are also observed in Idowu (2013) and Amusan and Luqman (2020), who maintain that the roles of the police include serving "as a "buffer between [the] elite and masses" and performing the essential task of operation against the mal-contents of the populace using coercive style and regimentation of social life in suppressing behaviours, actions and orientations that threaten the prevailing social order. Olukayode (2015) also argued that, given the increased spate of terrorism and violence across the globe, countries like Nigeria have resorted to the enforcement of domestic laws to regulate protests and riots in public places, which, as he acknowledged, threatens the basic tenets of democracy. Citing the Public Order Act, which makes it mandatory "for individuals or groups to apply for, and obtain police permit or approval to hold rallies and peaceful assemblies," he submitted that "[W]ith this law, the police commissioner 
in a state, acting on the instruction of the governor, is empowered to decide whether a group of people can hold protest demonstrations at all" (Olukayode, 2015:p. 37).

His analysis implies that the violation of human rights in Nigeria is a derivative of the constitution of the land since it is the police officers who decide when the Public Order is flouted or not. In other words, whether people should be allowed to protest is an entitlement that the law confers, and the police officers are allowed to decide the situations that should necessitate protest. If this view is accepted hook, line and sinker, then the future of human rights in Nigeria is very bleak.

In opposition to these prevailing analyses, we maintain that human rights abuse in Nigeria, before, during and after the \#ENDSARS protests by the state security services, is a result of the nature of the post-colonial character of the Nigerian state. Post-colonial states are the new nation-states that emerged out of the process of decolonization that intensified after the Second World War. Nigeria came into the orbit of British colonial domination between 1900 and 1960 . Colonialism began as a result of the changes in the mode of production in Europe; for example, the emergence of the industrial revolution, which necessitated the search for commodity goods and the market for refined commodities. As a result of direct political and economic domination by Britain, the Nigerian economy began to reflect the western capitalist economies. Ake (1981) explained how the Nigerian economy became absorbed into the global capitalist enterprise through the monetization of the Nigerian economy, the introduction of a tax system, confiscation of lands from the indigenous populations, disarticulation of the pre-colonial economy and the dependence of the local economy on the metropolitan economy. As a result of this development, many Nigerians, both in the urban and the rural areas, protested the harsh colonial policies. A typical example is the Aba Women Riot of 1929, which was crushed with all the imaginable repression and brutality from the Europeans. There were other pockets of riots and protests against the colonial policies, championed chiefly by a few Nigerians who had travelled abroad to study. Before long, they started to advocate independence. Granted, there was independence in 1960, but it did not amount to a fundamental liberation of Nigerians from the clutches of tyranny. This is because the nationalist petit bourgeoisie who fought for independence 
preferred political independence to a fundamental restructuring of the colonial economy (Ake, 1981). The reason is that these nationalists had no recognizable economic base before ascendency to the political post; and so, they perceived "access to the state and its patronage resources" as the key to their prosperity (Berman, 1998: 330).

Similarly, Alavi (1972) contended that the post-colonial state exhibits many features of the colonial states. According to him, the post-colonial states have a weak and underdeveloped indigenous bourgeoisie. This is because the post-colonial states were not established by the ascendant native bourgeoisie and, as a result, became relatively autonomous, mediating the interest of the metropolitan bourgeoisie, indigenous bourgeoisie and the landlords (Alavi, 1972). Furthermore, since the nationalist petit bourgeoisie are dependent on the superstructure (i.e., politics) to beef up their economic base, the state has become a means of production (Ekekwa, 1986). As a result of this excessive interventionist character of the Nigerian state in the economy, it has limited its autonomy (Ake, 1985), leading the state to inefficiency, wastefulness and misappropriation of the funds entrusted in its care for the citizens. The post-colonial state thrives in corruption (Beckman, 1988).

What then accounts for the authoritarianism of the Nigerian state, which the police and Nigerian army personify? It is the summation of the characteristics of the post-colonial state. This colonial spirit of the Nigerian state undermines its capacity to discharge the fundamental obligation of the state, which includes guaranteeing the fundamental human rights of its citizenry. Since the nationalist petit bourgeoisie that inherited power from the colonialists see politics as their preeminent profession, there is a "do or die" struggle for political power. The struggle for political power is so fierce that it is likened to war. Even when the political power is secured, it is characterized with "a winner-takes-all situation in which the losers lose everything, and the winner wins everything" (Mbah, Nwangwu and Edeh, 2017: 177). Since preeminent attention is given to using the state institution to acquire wealth, the state security services entrusted with the responsibility of protecting lives disregard their primary duties and see arresting individuals as a means of enriching themselves. This orientation is responsible for the impunity of the dissolved SARS. SARS extorted money from individuals and motorists who 
they arrest without a cause to the point that people could no longer bear with it, hence the protests.

Since the Nigerian state is corrupt, inefficient, non-productive, authoritarian, and embezzles money, it follows that the institutions of the state entrusted with the power to protect the lives of people and property would compromise in doing so. Since these institutions are corrupt, it follows that they will likely not arrest the real offenders. As a result, there is a high amount of impunity and a general breakdown of law and order.

In order to intimidate, subjugate and pacify the seemingly belligerent ethnic groups and to fast-track the gains of the indirect rule system, the colonial government adopted the police system as a means of reducing the cost of running the colonial bureaucracy. According to the Police Act of 1943, Section 4 provides five broad functions of the Nigeria Police Force, namely a) crime prevention, b) detection and apprehension of offenders, c) preservation of law and order, d) protection of life and property, and e) enforcement of all laws and regulations with which they are directly charged. These roles cover laws and regulations made by the federal, state and local governments (Nigeria Police Act, 1943) as cited in (Mmadubike and Obayemi,2019) Apart from these regulatory mechanisms, the 1999 constitution, which ought to serve as the people's document regulating police affairs, is a military manual and contains the seed of police violation of the fundamental human rights of Nigerians (Okonkwo, 2020). In the Police Act, emphasis is placed on the implementation of law and order at the detriment of the citizens' welfare. Until 2020 when the Nigeria Police Act was repealed by the National Assembly, little attention was paid to the authoritarian aspect of the Police Act, which the Nigeria Police inherited from the colonial regimes.

Nigerians perceive the entrenchment of police in the administration of the country as a strong source of force meant to grab the will and the desire of the government in power by force and not to exclusively protect laws and orders and legitimate fundamental human rights as contained in the 1999 constitution of the Federal Republic of Nigeria. Given this, Alemika and Chukwuma $(2000, p .3)$ opined that:

the public regard colonial police forces as their enemy, and as an instrument of violence and subjugation; as extortionists and harbingers of bad news and trouble. The perceptions of police 
by the people were grounded in their experience of the use of the military and constabulary forces during the earlier phase of the colonial campaign in various areas of the country."

The Europeans used them to crush all the revolts against their unpopular policies (Zumve, 2020). For instance, there was brutal repression of tax resistance in Lagos in 1903, 1908 and 1915; in Sapele in 1916; in Latok in 1917 and in Aba (i.e., the Aba Women Riot) in 1929 in which 50 women were killed and many more injured (Nnoli, 2011). As Nigeria got its independence, the petit bourgeoisie that replaced the colonial masters continued using the police to suppress people's resistance to harsh post-colonial policies (Nnoli, 2011).

The intensification of the use of force and the violation of the fundamental human rights of the people of Nigeria came to a head during the long years of military rule. This is understandable given that the nature and character of the military as an institution is in dialectical opposition to the institution of democracy under which human rights thrive. While the military addresses an extreme situation and serves as a tool of violence, democracy thrives on consensus and negotiation (Nnoli, 2011).
Given this scenario, the military in government will likely encroach on human rights. The Murtala/Obasanjo regime sacked senior civil servants without due process and threatened people with detention. It also promulgated the Land Use Decree of 1978 that gave the control of the land to the government instead of the people. The regime equally constrained people's right to assembly and banned labour unions from embarking on strikes. In addition, the military regimes of Ibrahim Badamasi Babangida and Sani Abacha performed woefully on the human rights index (Nnoli, 2011). Since the return of Nigeria to democratic practice, the police are alleged to have been involved in the torturing of suspects, extrajudicial killings-there is an almost complete absence of victims protection and a sense of justice (Muller, 2020). Amnesty International (2009) equally reported that the Nigerian police killed about 7,198 armed robbers and injured 575 individuals without proper trial in the year 2000.

Institutional mechanisms of human rights protection in Nigeria

It should be stated that over the years, the fundamental human rights of people have been protected and preserved through various institutional mechanisms. This is because, human rights are rights inherent 
to all human beings, regardless of race, sex, nationality, ethnicity, language, religion, or any other status", deprivation of which amounts to a denial of justice (https://www.un.org/en/globalissues/human-rights). Sagay (2010) observed that there are three great historical antecedents that condition the practice of human rights in various countries of the world, namely the Magna Carta of 1215 in England, the declaration of independence by thirteen American colonies in 1776 and the French Revolution in 1789. The Magna Carta provided that "no freeman shall be taken or imprisoned or deceased or outlawed except by the laws of the land." In England, it is seen as a sacred text against the voices of oppression and tyranny. The same principle is equally found in the preamble of the American constitution, which states that all men are created equal and have certain inalienable rights that the government can protect.

The French Revolution of 1789 differed from the English and American ones because it was aimed at the demolition of an old absolutist system of government and the establishment of a democratic order within the system. Apart from these old documents, there is in recent times the Universal Declaration of Human Rights (UDHR) as a global institutional check against tyranny (Madubuike-Ekwe \& Obayemi, 2019). Its evolution owes much to the desire of humanity not to repeat the barbarism and horrors committed by Nazi Germany against the Jews. The horrors of the international community found expression in the first statements of the UDHR, which recognized the inalienable rights of all members of human families as the foundation of freedom and justice. As a result of this development, fundamental human rights are incorporated into various constitutions of members of the United Nations (UN). For instance, Article 4 of the Constitution of the Federal Republic of Nigeria provides for different kinds of wide-ranging fundamental human rights. And in Article 8 of the constitution, the court is empowered to defend these fundamental human rights as enshrined in the constitution.

Apart from the constitution serving as a bulwark against the abuse of fundamental human rights, there are other agencies, such as the National Human Rights Commission (NHRC), the Public Complaints Commission and the Truth and Reconciliation Commission, established to create an enabling environment for the recognition, promotion and enforcement of human rights, treaty obligations and providing a forum for public 
enlightenment and dialogue on human rights issues. These platforms help to limit controversies and confrontations. The NHRC is mandated "to deal with all matters relating to the protection of human rights as guaranteed by the Constitution of the Federal Republic of Nigeria, African Charter, the United Nations Charter and the Universal Declaration on Human Rights and other international treaties on human rights to which Nigeria is a party to its treaty" (Nnamani, 2011).

The Public Complaint Commission has wide powers to inquire into complaints by members of the public concerning the administrative action of any public authority and companies or their officials and others. The Act equally provides that in every case where a commissioner of the commission discovers that a crime may have been committed by any person, he shall report his findings to the appropriate authority or recommend that the person be prosecuted (Nnamani, 2011).On its own part, the Truth and Reconciliation Commission was originally established in 1999 by the administration of Olusegun Obasanjo to look into the human rights abuse perpetrated by the military regime of Sani Abacha from 1993 to 1998. It was later broadened to include the activities of the past military regimes in connection with human rights abuse. The commission was headed by Chikwudifu Oputa. Before the commission was established, virtually all the agencies of security services in Nigeria were scored low on the issue of human rights. In the same way, all the above-mentioned agencies failed Nigerians on the day they sought help regarding the brutality of police SARS against innocent Nigerians (Amnesty International, 2020). 
Table1: Constitutional fundamental human rights that were violated before and during the \#EndSars protest

\begin{tabular}{|c|c|c|}
\hline $\begin{array}{l}\text { Freedo } \\
m \text { of } \\
\text { Expressi } \\
\text { on }\end{array}$ & $\begin{array}{l}\text { Section } 39 \text { CFRN; } \\
\text { art } 9 \text { ACHPR art } 19 \\
\text { UDHR }\end{array}$ & $\begin{array}{l}\text { These provisions grant every Nigerian the freedom to } \\
\text { receive and express their opinions, ideas and } \\
\text { information. It also grants them the right to } \\
\text { establish and operate any medium used in } \\
\text { disseminating information in Nigeria subject to the } \\
\text { regulations of wireless broadcast. }\end{array}$ \\
\hline $\begin{array}{l}\text { Right to } \\
\text { Life }\end{array}$ & $\begin{array}{l}\text { Section } 33 \text { CFRN; } \\
\text { art } 4 \text { ACHPR; art } 3 \\
\text { UDHR. }\end{array}$ & $\begin{array}{l}\text { Everyone has a right to life, and no one must be } \\
\text { deprived of his life intentionally. The exceptions to } \\
\text { this right are: 1) a valid death sentence by a court of } \\
\text { law; 2) where a person dies during the use of } \\
\text { reasonable force while engaging in self-defence, and } \\
\text { 3) where a person dies while affecting a lawful arrest } \\
\text { or suppressing a riot, mutiny or insurrection provided } \\
\text { reasonable force is used. }\end{array}$ \\
\hline $\begin{array}{l}\text { Freedo } \\
m \text { of } \\
\text { Associa } \\
\text { tion }\end{array}$ & $\begin{array}{l}\text { Section } 40 \text { CFRN; } \\
\text { art } 10 \text { and } 11 \\
\text { ACHPR; art } 17 \text { and } \\
20 \text { UDHR. }\end{array}$ & $\begin{array}{l}\text { Every Nigerian is entitled to form or join any } \\
\text { association of people in Nigeria in support of his } \\
\text { interest. }\end{array}$ \\
\hline $\begin{array}{l}\text { Right to } \\
\text { Dignity } \\
\text { of Life }\end{array}$ & $\begin{array}{l}\text { Section } 34 \text { CFRN; } \\
\text { art } 4 \text { ACHPR; art 1, } \\
4,5 \text { and } 6 \text { UDHR }\end{array}$ & $\begin{array}{l}\text { Every individual is entitled to dignity and respect. He } \\
\text { is entitled to be free from slavery and torture }\end{array}$ \\
\hline $\begin{array}{l}\text { Right to } \\
\text { Liberty }\end{array}$ & Section 35 CFRN & $\begin{array}{l}\text { Every Nigerian has the right to personal liberty, and } \\
\text { no person should be deprived of this right except 1) } \\
\text { in the execution of a criminal sentence by a court of } \\
\text { law; 2) for } \\
\text { failure to comply with an order of a court; } 3 \text { ) in } \\
\text { bringing him before a court; } 4 \text { ) in preventing him } \\
\text { from committing an offence; 5) where he is } \\
\text { reasonably suspected of committing an offence; and } \\
\text { 6) for care and treatment for persons with infectious } \\
\text { disease, unsound mind or addictions. }\end{array}$ \\
\hline $\begin{array}{l}\text { Freedo } \\
m \text { of } \\
\text { Movem } \\
\text { ent }\end{array}$ & $\begin{array}{l}\text { Section } 41 \text { CFRN; } \\
\text { art } 12 \text { ACHPR; art } \\
13 \text { UDHR. }\end{array}$ & $\begin{array}{l}\text { Every Nigerian has the right to move anywhere in } \\
\text { Nigeria. This right, however, does not apply where a } \\
\text { person has been lawfully sentenced to imprisonment } \\
\text { or restricted by a court of law. }\end{array}$ \\
\hline
\end{tabular}

Source: Adopted from Chisom (2021) 
Empirical incidences of SARS brutalities the youthful population that participated on Nigerians before the \#EndSARS protest in the \#EndSARS protest. All of the As can be observed from Table 1 above, causalities were the young ones who were everyone has a right to life, and no one still in the bloom of their youth. The must be deprived of his life intentionally. protest participants had the belief that it Table 2 also contains records of so many deaths, ranging from those dying in the custody of police in various police stations to those who died by stray bullets from the police without any compensation from the police authority.

The data in the table also reveal that it was is their age bracket that bore the most attack from the SARS, and so a fight for the dead was a fight for their protection. And most tellingly, the data reveal a southern geographical bias, thus amplifying the rationale behind northern lethargy against the \#EndSARS protest. 
Table 2: Victims of SARS and Human Rights Abuse before the \#EndSARS Protest

\begin{tabular}{|c|c|c|c|c|}
\hline Names of Victims & Age & State & Date Killed & Nature of Death \\
\hline $\begin{array}{l}\text { Daniel Adewuyi } \\
\text { Tella }\end{array}$ & 27 & Lagos & 07/02/2006 & $\begin{array}{l}\text { Graduate of Banking and } \\
\text { Finance arrested on his way } \\
\text { home in FESTAC. Died in police } \\
\text { custody }\end{array}$ \\
\hline $\begin{array}{l}\text { Godgift Ferguson } \\
\text { Ekerete }\end{array}$ & 24 & Rivers & 03/07/2008 & $\begin{array}{l}\text { Killed in Mile One Police } \\
\text { Station in Port Harcourt }\end{array}$ \\
\hline Tony Oruama & 21 & Rivers & 03/07/2008 & $\begin{array}{l}\text { Killed in Mile One Police } \\
\text { Station in Port Harcourt }\end{array}$ \\
\hline Harry Ataria & 26 & Rivers & 03/07/2008 & $\begin{array}{l}\text { Killed in Mile One Police } \\
\text { Station in Port Harcourt }\end{array}$ \\
\hline Mbakwe Oruama & 20 & Rivers & 03/07/2008 & $\begin{array}{l}\text { Killed in Mile One Police } \\
\text { Station in Port Harcourt }\end{array}$ \\
\hline Emmanuel Egbo & 15 & Enugu & $25 / 09 / 2008$ & $\begin{array}{l}\text { Playing with his fellow children } \\
\text { and was unarmed when killed } \\
\text { by SARS }\end{array}$ \\
\hline Chika Ibeku & 29 & Rivers & 09/04/2009 & $\begin{array}{l}\text { First arrested and detained at } \\
\text { Omoku Police station, then } \\
\text { transferred to Port Harcourt. To } \\
\text { date, their whereabouts is } \\
\text { unknown }\end{array}$ \\
\hline Gabriel Ejoor & 23 & Rivers & 09/04/2009 & Arrested with Chika Ibeku \\
\hline Precious Odua & 21 & Rivers & 09/04/2009 & Arrested with Chika Ibeku \\
\hline Owoicho & 29 & Rivers & 09/04/2009 & Arrested with Chika Ibeku \\
\hline Christian Onuigbo & 28 & Abuja & & $\begin{array}{l}\text { Shot by the police while } \\
\text { parking his car in Jiwa }\end{array}$ \\
\hline Kolade Johnson & 22 & Lagos & $31 / 03 / 2019$ & Killed by police stray bullet \\
\hline Mus'ab Sammani & 22 & Kano & $4 / 12 / 2019$ & $\begin{array}{l}\text { Shoot by the police over an } \\
\text { argument between him and a } \\
\text { Keke driver that bashed his car }\end{array}$ \\
\hline Chima & N/A & Rivers & $23 / 12 / 2019$ & $\begin{array}{l}\text { Arrested by the police in Port } \\
\text { Harcourt and was tortured to } \\
\text { death }\end{array}$ \\
\hline Kazeem Tiamiyu & 21 & Ogun & $22 / 02 / 2020$ & $\begin{array}{l}\text { Assistant Captain of Remo } \\
\text { Stars Football Club harassed } \\
\text { and killed by SARS }\end{array}$ \\
\hline
\end{tabular}




\begin{tabular}{|l|l|l|l|l|}
\hline Tina Ezekwe & 16 & Lagos & $14 / 05 / 2020$ & $\begin{array}{l}\text { Secondary school student that } \\
\text { was shot and killed by two } \\
\text { police officers at the lyana- } \\
\text { Oworo area of Lagos State }\end{array}$ \\
\hline $\begin{array}{l}\text { Chibuike Daniel } \\
\text { Ikeaguchi }\end{array}$ & 20 & Rivers & $19 / 09 / 2020$ & $\begin{array}{l}\text { Upcoming music artiste. Went } \\
\text { to visit his friend at Elelenwo } \\
\text { area of Obio Akpor Rivers State } \\
\text { but was killed by SARS on his } \\
\text { return }\end{array}$ \\
\hline
\end{tabular}

Source: Adopted from the reports of Amnesty International (2006, 2008, 2009, 2018, 2019 \& 2020) and prepared by the authors.

Table 3: Victims of \#EndSARS Protest and Abuse of Human Rights during the Protest

\begin{tabular}{|c|c|c|c|c|}
\hline $\begin{array}{l}\text { Names of } \\
\text { Victims }\end{array}$ & Source & State & Date Killed & Nature of Death \\
\hline Unnamed & $\begin{array}{l}\text { Harvard } \\
\text { Human Right } \\
\text { Review }\end{array}$ & Delta & $3 / 10 / 20$ & $\begin{array}{l}\text { Report of the unprovoked } \\
\text { shooting of a boy on the } \\
\text { street of Delta State, whose } \\
\text { care was snatched by SARS } \\
\text { official }\end{array}$ \\
\hline Jimoh Isiaka & $\begin{array}{l}\text { Human Right } \\
\text { Watch }\end{array}$ & Oyo & $10 / 10 / 20$ & $\begin{array}{l}\text { He was killed by a stray } \\
\text { bullet while the police were } \\
\text { dispersing protesters in } \\
\text { Ogbomosho }\end{array}$ \\
\hline Unnamed & $\begin{array}{l}\text { Vanguard } \\
\text { Newspaper }\end{array}$ & Ondo & $11 / 10 / 20$ & $\begin{array}{l}\text { The police shot tear gas and } \\
\text { live bullets to disperse } \\
\text { protesters, killing about } 4 \\
\text { persons }\end{array}$ \\
\hline Unnamed & $\begin{array}{l}\text { Amnesty } \\
\text { International }\end{array}$ & All & $12 / 10 / 20$ & $\begin{array}{l}\text { Amnesty International } \\
\text { reported that the police } \\
\text { killed about } 10 \text { persons in } \\
\text { one week during the } \\
\text { protest }\end{array}$ \\
\hline Unnamed & Nairametrics & Abuja & $12 / 10 / 2020$ & $\begin{array}{l}\text { As the protesters were } \\
\text { heading towards Force } \mathrm{HO} \text {, } \\
\text { the police attacked them } \\
\text { using teargas, water } \\
\text { cannons and gunshots, }\end{array}$ \\
\hline
\end{tabular}




\begin{tabular}{|c|c|c|c|c|}
\hline & & & & $\begin{array}{l}\text { slashing car tyres, seized } \\
\text { phones and arrested others }\end{array}$ \\
\hline Unnamed & Nairametrics & Rivers & $12 / 10 / 20$ & $\begin{array}{l}\text { The banning of protest by } \\
\text { Governor Nyesom Wike, } \\
\text { thus stopping the planned } \\
\text { protest on Tuesday of that } \\
\text { week }\end{array}$ \\
\hline Unnamed & Nairametrics & Lagos & $13 / 10 / 20$ & $\begin{array}{l}\text { As the police dispersed } \\
\text { protesters in Surulere, } 1 \\
\text { person was killed, and } \\
\text { others were arrested and } \\
\text { kept in police stations }\end{array}$ \\
\hline Unnamed & $\begin{array}{l}\text { ThisDay } \\
\text { Newspaper }\end{array}$ & Abuja & $14 / 10 / 20$ & $\begin{array}{l}\text { An order from the CBN to } \\
\text { various banks not to allow } \\
\text { their platforms to be used } \\
\text { for raising funds }\end{array}$ \\
\hline Unnamed & $\begin{array}{l}\text { ThisDay } \\
\text { Newspaper }\end{array}$ & Abuja & $15 / 10 / 20$ & $\begin{array}{l}\text { The announcement by the } \\
\text { Federal Capital Territory } \\
\text { Administration that all } \\
\text { demonstrations have been } \\
\text { banned after a wave of } \\
\text { \#EndSARS protests in } \\
\text { various cities }\end{array}$ \\
\hline Unnamed & Nairametrics & Lagos & $20 / 10 / 20$ & $\begin{array}{l}\text { Peaceful protesters were } \\
\text { allegedly shot at by the } \\
\text { Nigerian military at the } \\
\text { Lekki Tollgate, in which } 49 \\
\text { persons were alleged to be } \\
\text { killed }\end{array}$ \\
\hline $\begin{array}{l}\text { Unnamed } \\
\text { woman }\end{array}$ & $\begin{array}{l}\text { Human Rights } \\
\text { Watch }\end{array}$ & Оуо & & $\begin{array}{l}\text { A woman was severely } \\
\text { beaten by a stick by the } \\
\text { police, fracturing her skull }\end{array}$ \\
\hline $\begin{array}{l}\text { Ikechukwu } \\
\text { Ilohamauzo }\end{array}$ & HRW & & $12 / 10 / 20$ & $\begin{array}{l}\text { Police opened gunfire to } \\
\text { disperse protesters, killing } \\
55 \text {-year-old IK }\end{array}$ \\
\hline Unnamed & HRW & & $12 / 10 / 20$ & $\begin{array}{l}\text { Police arrested dozens of } \\
\text { protesters, who were } \\
\text { refused access to their }\end{array}$ \\
\hline
\end{tabular}


lawyers but were released

following the intervention of some prominent political office holders

The data in Table 3 show that what triggered the protest was the report of the unprovoked shooting of a boy in Delta State and the snatching of his car by the SARS official. The table also reveals the application of live bullets by the police to disperse protests in contradistinction to various human rights principles and rules of engagement between the police and the people. And as in the cases of SARS brutalities before the 2020 protests, the youthful population bore the larger consequences of the brutalities. During the protests in Lagos State, the protesters were at Lekki Toll Gate, demanding the dissolution of SARS when the military came and opened fire on the demonstrators. There are different accounts regarding the number of people that died (Premium Times, 27 November 2020). Apart from the brutalization of the protesters at Lekki, it has been established that the police used live bullets to quell the crisis. According to General Ahmad Taiwo, Commander of 81 Military Intelligence, Victoria Island, the majority of bullets used by the soldiers during the protest was live bullets. There was also the killing of Jimoh Isiaka in Oyo state and others in various states by the police, as reported by Human Rights Watch (2020). As the above tables have shown, the constitution bequeaths on the citizens the right to freedom of association, freedom of movement, freedom of expression, right to life, right to dignity of life and right to liberty, but the government trampled upon them before, during and even after the \#EndSARS protests.

\section{Conclusion}

We have demonstrated that the brutality of the Nigerian police, or specifically the Special Anti-Robbery Squads (SARS), is not a spur of the moment action or a spontaneous event; rather, it is a pattern and routine that is traceable to the colonial orientation of the Nigerian police and the nature of post-colonial character of the Nigerian state. We highlighted how the contents of the Nigeria Police Act and the Public Order Act infringe on the fundamental human right of the citizens, who decided to express their dissatisfaction with the situation through protests. In addition, the study demonstrated the ignoble role of the police in wasting the lives of some youths, 
which triggered the \#EndSARS protests, a the inalienable entitlements of all situation that, ironically, continued during humanity to these rights despite their the protest. The study was a departure from extant analyses of the \#EndSARS protest because through the theory of the state in a post-colonial society, with its major assumption of state's interventionist character, weak economic base, corruption and embezzlement of funds and dependency, the study narrowed the explanation down to the action and inaction of the government functionaries, especially those wielding the apparatus of force whose quest for the material gains compromise their constitutional job specifications as agents for the protection of people's fundamental human rights.

There is, therefore, the need to reorient the police about their job specifications and race, geography, material wealth and the disposition of those at the helm of affairs. The government can start this by recruiting those who have a passion for humanity into the police force and establishing a retraining process that periodically appraises the state of human rights compliance among police officers. There is the need also for the youth to develop a different negotiating skill other than protests and to apply restraint under provocation, given that the greater percentage of those who have lost their lives before, during and after the protests are the youth. Finally, when those who govern the masses follow the spirit and letters of the constitution, it will lessen the antagonism between the governors and the governed. 


\section{References}

Alemika, E. E. O. and Chukwuma I.C. (2000) - Police-Community Violence in Nigeria (Centre for Law Enforcement Education, Lagos and the National Human Rights Commission, Abuja, Nigeria).

Aborishade, A. \& Obileye, A. A. (2018). A Systematic Brutality, Torture and Abuse of Human Rights by the Nigerian Police: Narratives of Inmates in Ogun State Prisons. The Nigerian Journal of Sociology and Anthropology, 15(1), no 1.

Agbiboa, Daniel E. "'Policing is not work: it is stealing by force': corrupt policing and related abuses in everyday Nigeria." Africa Today, vol. 62, no. 2, 2015, p. 95+. Gale Academic OneFile.

Ake, C. ( 1981). Political Economy of Africa. London: Longman.

Ake, C. (1985). The Future of the State (1985), International Political Science Review, Vol. 6 No. 1, pp. 105-114.

Alavi, H. (1972) 'The State in Post-colonial Societies: Pakistan and Bangladesh', New Left Review 74: 59-81.

Amnesty International (2009). Nigeria Human rights in perspective. Amnesty International Submission to the UN Universal Periodic Review.pp.6-9.

Amnesty International (2018). Nigeria: Still no Accountability for Human Rights Violations Amnesty international Submission for the Universal Periodic Review - 30th Session of the UPR Working Group.pp.24-37.

Amnesty International (2020). The States of the World's Human Right.pp.268-271.

Amusan, L. \& Lukman, S. (2020). The Nigerian Police Force and the Task of Policing Democratic Nigeria: Issues and Problems. Anthropologist 31(1-3): 105-116 (2018) DOI: 10.1080/09720073.2018.1439782

Amuta, C. (2020). SARS, Youth Spring and Beyond. ThisDay Newspaper, 18 October

Appadorai, A. (1974). The Substance of Politics. New Delhi: Oxford University Press.

Bechman, J. (1988). Post-colonial State-Crisis and Reconstruction. IDS Bulletin, 9(4), pp. 89103.

Berman, B.J. (1998). Ethnicity, patronage and the African state: The Politics of uncivil nationalism. African Affairs (1998), 97, 305-341. 
Brogden, M. (1987). The emergence of the police-the Colonial Dimension. British Journal of Criminology, 27(1), pp. 72-94.

Chisom 0. B (2021). Democracy and Right to Freedom of Expression: A Case Study on the Nigerian Youth Protest on Police Brutality. Open Journal of Political Science, 11, pp. $.34-53$.

Cilliers, J. J. (2018). Violence in Africa: Trends, Drivers and Prospects to 2023. Africa Report 12 , Available at SSRN: https://ssrn.com/abstract=3254122

Dyzenhaus, D. (1992). Why Positivism is Authoritarian. The American Journal of Jurisprudence, 37(1), pp. 83-112.

Ekekwe, E. (1986). Class and State in Nigeria. Longman, London.

Eranga, I. 0. (2020). COVID-19 Pandemic in Nigeria: Palliative Measures and the Politics of Vulnerability. International Journal of MCH and AIDS, 9(2), pp. 220-222.

Garcia, A. (2017). Natural law and human rights- Catholic proposal towards a common base for interreligious dialogue. Revista Advocatus, vol. 2, n² 29, p.1-

Ibeanu, 0. (1993). The State and the Market: Reflections on Ake's Analysis of the State in the Periphery. Africa Development, 18(3), pp. 117-131.

Idowu, J. (2013), Policing in Contemporary Nigeria: Issues and Challenges. In African Journal for the Psychological Study of Social Issues.Vol.16No. 1.

International Police Science Association (2016). World Internal Security \& Police Index.'Trends in Internal Security and Policing, Results and Outcomes.pp.28-40.

Interpol Annual Report. (2019). Nigeria...Enforced Disappearances, Extrajudicial Killings and unlawful Detention. Pp. 6-7.

Invernizzi-Accetti, C. (2017). Reconciling legal positivism and human rights: Hans Kelsen's argument from relativism. Journal of Human Rights, Journal of Human Rights, Vol.17.pp.1-17.

Lyle, P. \& Esmail, A. (2016). Sworn to Protect: Police Brutality - A Dilemma for America's Police. Race, Gender \& Class, 23(3-4), 155-185.

Madubuike-Ekwe, Ndubuisi J. and Obayemi, D. Olumide K. (2019) "Assessment of the Role of the Nigerian Police Force in the Promotion and Protection of Human Rights in Nigeria," Annual Survey of International \& Comparative Law: Vol. 23 : Iss. 1 , Article 3. Available at: https://digitalcommons.law.ggu.edu/annlsurvey/vol23/iss $1 / 3$ 
Maduka, C . (2014). The Impact of Training in the Nigerian Police Force: A Study of Zone 9 Umuahia. International Journal of Social Sciences and Humanities Invention, 1(5), pp. 326-343.

Mbah, P., Nwangwu, C. \& Edeh, H. (2017). Elite politics and the emergence of Boko Haram Insurgency in Nigeria. Trames, 21(71/66), pp. 173-190.

Mehmet R. D (2015) Natural Law Theory, Legal Positivism, and the Normativity of Law, The European Legacy, 20:8, 807-826, DOI: 10.1080/10848770.2015.1078991

Müller, N. (2020). Nigeria's Police Work between International Reform Ideas and National Security Arrangements. (PRIF Working Papers, 48). Frankfurt am Main: Hessische Stiftung Friedens- und Konfliktforschung. https://nbnresolving.org/urn:nbn:de:0168-ssoar-69033-6

Nnamani, S.O (2011). Institutional mechanisms for human rights protection in Nigeria: an appraisal, Journal of International Law and Jurisprudence, Nnamdi Azikiwe University, Vol. 2

Nnoli, O. (2003). Introduction to politics. Snaap press Ltd. Enugu, Nigeria.

Nnoli, 0. (2011). The Struggle for Democracy in Nigeria. Snaap press Ltd. Enugu, Nigeria.

Nzarga, F . (2014). An Analysis of Human Rights Violation by the Nigerian Security Services Journal of Law, Policy and Globalization, 30, pp. 1-8.

Okolie, M. A. (2008). State, Institutionalized Personality Cult and Participatory Democratic Culture in Nigeria,1999-2005. University of Nigeria Journal of Political Economy, 2(1\&2), pp.70-85.

Okonkwo U. U. (2020) The Constitution and the State of the Local Government System in Nigeria. Ikoro Journal of Contemporary African Studies, 14(1), pp.

Olaigbe, T. (2021). Youths' perception and contributing factors towards jungle justice during Endsars protests in Nigeria. African Journal for the psychological study of social issues, 24(1), pp. 181-192.

Olufasi E (2020). Travel ban, lockdown, protest... how COVID-19, \#EndSARS shaped 2020 ThisDay, Newspaper, 25 October.

Olukayode, E . (2015). Protest Demonstrations, Political Participation and the Law in the Era of Terrorism: Nigeria's Public Order Act and the United States' HR 347 in Perspectives. International Journal of Arts and Humanities,4(2), pp. 28-41.

Olusegun A (2020) Dealing with the SARS Menace. ThisDay, Newspaper, 8 October. 
O'Manique, J. (1992). Development, Human Rights and Law. Human Rights Quarterly, 14(3), pp. 383408.

Onuoha, J. (1992). What is the State? Nsukka: Great AP Publishers Limited.

Oromareghake, P. Oluka, N. L. \& Adishi, E. (2018). The Nigerian Police and Legitimacy Crises: A focus on Human Rights Abuses and Protection in Contemporary Nigeria. Journal of Public Administration and Social Welfare Research, 3(2), pp. 3-14.

Pillay, S. \& Scanlon, H. (2008). Peace versus justice?: truth and reconciliation commissions and war crimes tribunals in Africa. Centre for conflict resolution. http://www.jstor.org/stable/resrep05153.7

Sagey, I. (2010) The Protection of Human Rights in International Law. In F. Adegbulu (ed), Topics and Issues International Relations. Ilishan Remo: Babcock University Press.

Tendaishe T (2020) Revisiting Peace and Reconciliation in Africa: taking Stock of African Truth Commissions' Progress and Challenges Thus Far. Ikenga International Journal of Institute of African Studies Volume, 21(1 \& 2), pp.1-12.

ThisDay, Newspaper, Wednesday, 21 October, (2020). Death at Dusk for Young \#Endsars Protesters. Pp.2-3.

ThisDay, Newspaper, Friday, 30 October, (2020). Buhari in Deafening Silence Over Lekki Shootings, Urges End to Protest.

Usman, A. Ogunleye, 0. \&Aderinto, A. (2021). Mass mobilization for police Accountability: The case of Nigeria's \# endsars protest. Policing, Volume 2, Number 7, pp. 1-10

Uwazurike, A. R. (2020). \#EndSARS: The Movement Against Police Brutality in Nigeria. Harvard Human Rights Journal. PP. 83-96.

Valentin, L. (2012). In What Sense are Human Rights Political? A Preliminary Exploration of political studies, 60, pp. 180-194.

Vanguard, Newspaper, Thursday, April 16 2020. What to know About Nigeria \#Endsars Protest.p.16.

World Report, Human Rights Watch (2010). The Abuser's Reaction. Intensifying Attacks on Human Right Defenders, Organizations \& Institutions.pp.17.

Zumve, I. (2020). The political economy of the \#endsars protest in Nigeria: opening the "black box" of police brute-force and extrajudicial executions. International Journal of Social Sciences and Humanities Reviews, 10(3), p. 132-139 